Novos Estudos Jurídicos

\title{
QUALIDADE DA ÁGUA: UM ENFOQUE JURÍDICO E INSTITUCIONAL DO REÚSO INDIRETO PARA FINS POTÁVEIS
}

\author{
WATER QUALITY: A LEGAL AND INSTITUTIONAL APPROACH TO INDIRECT REUSE FOR \\ DRINKING PURPOSES
}

\section{CALIDAD DEL AGUA: UN ENFOQUE JURÍDICO E INSTITUCIONAL DEL REÚSO INDIRECTO PARA FINES POTABLES}

\section{Maria Luiza Machado Granziera ${ }^{1}$}

Licença CC BY: Artigo distribuído sob os termos Creative Commons, permite uso e distribuição irrestrita em qualquer meio desde que o autor credite a fonte original.

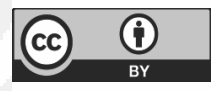

\begin{abstract}
Resumo: O artigo trata do reúso indireto não planejado de água para fins potáveis no Brasil, tema associado à qualidade e à gestão dos recursos hídricos. O estudo parte de uma análise das normas sobre qualidade da água, abordando a realidade da diluição de efluentes domésticos à luz das normas vigentes. O objetivo é demonstrar a importância da articulação institucional e da governança entre União, Estados e Municípios na solução dos problemas da poluição da água causada pelos esgotos domésticos. A metodologia constitui-se de pesquisa exploratória e qualitativa, utilizando bibliografia baseada em doutrina, princípios e normas relacionadas ao assunto. Concluiu-se que uma forma adequada de enfrentar o problema consiste na articulação entre o planejamento das bacias hidrográficas e os planos municipais de saneamento básico, grande desafio para os atores envolvidos no processo.
\end{abstract}

Palavras-chave: qualidade da água; efetividade das normas; articulação institucional; governança; reúso.

Abstract: The paper address indirect reuse of water for drinking purposes in Brazil, which is related to water quality and water management. The study starts with an analysis of water quality standards, addressing the reality of untreated discharge of domestic effluents. The aim is to demonstrate the importance of institutional articulation and governance between the Federal Government, States and Municipalities in solving water pollution problems caused by domestic sewage. The methodology consists of exploratory and qualitative research, using bibliographies based on doctrine, principles and norms related to the subject.

1 Advogada. Mestre em Direito Internacional e Doutora em Direito pela Universidade de São Paulo (EDUSP). Professora Associada ao Programa de Pós-Graduação Stricto Sensu em Direito da Universidade Católica de Santos, Estado de São Paulo, Brasil. Autora dos livros "Direito Ambiental”, 2015, 4.ed., e "Direito de Águas Disciplina Jurídica das Águas Doces”, 4.ed., 2014, entre outros trabalhos. E-mail: marialuiza.granziera@gmail.com. 


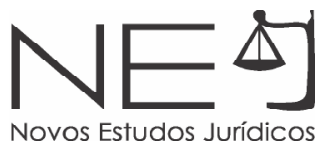

It concludes that an adequate way of dealing with the problem is cooperation between river basin planning and municipal sanitation plans, which is a great challenge for those involved in the process.

Key-words: water quality; effectiveness; institutional articulation; governance; reuse.

Resumen: El artículo trata del reúso indirecto no planificado del agua para fines potables en Brasil, tema asociado a la calidad y a la gestión de los recursos hídricos. El estudio parte de un análisis de las normas sobre calidad del agua, abordando la realidad de la dilución de efluentes domésticos a la luz de las normas vigentes. El objetivo es demostrar la importancia de la articulación institucional y de la gobernanza entre Unión, Estados y Municipios en la solución de los problemas de la polución del agua causada por los desagües domésticos. La metodología se constituye de investigación exploratoria y cualitativa, utilizando bibliografía basada en doctrina, principios y normas relacionadas al asunto. Se concluye que una forma adecuada de enfrentar el problema consiste en la articulación entre la planificación de las cuencas hidrográficas y los planos municipales de saneamiento básico, grande desafío para los actores envueltos en el proceso.

Palabras - clave: calidad del agua; efectividad de las normas; articulación institucional; gobernanza; reúso.

\section{INTRODUÇÃO}

Dados do Atlas Brasil - Abastecimento Urbano de Água, da Agência Nacional de Águas² - apontam que dos 5.565 municípios brasileiros estudados, correspondentes a uma demanda de 570,2 m³/s em 2015, 2.506 municípios encontram-se em situação satisfatória, 2.551 demandam ampliação de sistema e 472 requerem novos mananciais. Para 2025, é prevista uma demanda de 630,4 m³ com uma proposta de investimento de $R \$ 22.233,36$ milhões em 3.069 municípios.

Essas informações, associadas ao quadro de escassez hídrica ocorrido nos últimos anos em várias partes do Brasil, explicitam a fragilidade qualitativa e quantitativa de muitos mananciais e, também, a necessidade de buscar alternativas de segurança hídrica para épocas de poucas chuvas. Considerando que as alterações do clima de maneira geral tendem a intensificar tanto a pluviometria quanto a estiagem, é imprescindível o estudo de novas possibilidades para a obtenção segura do recurso para o abastecimento humano, sem desconsiderar o meio ambiente ecologicamente equilibrado e a proteção da saúde das populações.

2 AGÊNCIA NACIONAL DE ÁGUAS. Atlas Brasil - Abastecimento Urbano de Água. Brasília, 2015. Disponível em: <http://atlas.ana.gov.br/Atlas/forms/Home.aspx. Acesso em: 12 dez. 2017>. 
O presente artigo tem por objetivo analisar o reúso indireto não planejado da água para fins potáveis, prática amplamente adotada no país, mas sem regras específicas para sua operação. Buscar soluções normativas ou negociadas para esse tipo de reúso, que sejam efetivamente cumpridas pelos atores envolvidos por meio de um processo de governança, corresponde a uma alternativa estratégica para o futuro. A metodologia constitui-se de pesquisa exploratória e qualitativa, utilizando bibliografia baseada em doutrina, princípios e normas relacionadas ao assunto.

Em primeiro lugar, cumpre caracterizar o objeto da pesquisa - reúso indireto não planejado para finalidades potáveis. Em termos legais, será analisada a estrutura normativa vigente no Brasil com rebatimento na qualidade da água, no uso racional e, especificamente, na questão do reúso para fins potáveis, tema que se refere diretamente ao abastecimento de água potável, atividade que integra, juntamente com o esgotamento sanitário, a limpeza urbana e o manejo de resíduos sólidos urbanos, além da drenagem e do manejo das águas pluviais urbanas, o conjunto dos serviços de saneamento básico fixados na Lei n 11.445/2007.

Sob o aspecto institucional, serão indicados os atores envolvidos na matéria e as possibilidades de exercício de governança entre eles sem excluir a sociedade, com vistas a buscar soluções exequíveis e realísticas para as questões apontadas.

O tema envolve o meio ambiente, a gestão dos recursos hídricos e o saneamento básico. O reúso da água alinha-se com a ideia do uso racional dos recursos ambientais, um dos objetivos primordiais da Política Nacional do Meio Ambiente (PNMA), instituída pela Lei n 6.938/1981. Considerando que o domínio das águas, definido pela Constituição, é da União e dos Estados (e Distrito Federal), e que a titularidade dos serviços públicos de saneamento básico, que impactam fortemente a qualidade das águas, é atribuída aos Municípios, fica explicitada a necessidade de cooperação e articulação entre esses Entes Federados, por intermédio de seus órgãos e entidades. Nesse sentido, a falta do exercício de governança entre os atores mencionados é uma das razões para a situação de poluição em que se encontram os corpos hídricos ${ }^{3}$.

3 HOEKSTRA, Arjen Y. Sustainable, efficient, and equitable water use: the three pillars under wise freshwater allocation. WIREs Water, jan./fev. 2014, v. 1, p. 31-40. Doi: 10.1002/wat2.1000. Disponível em: <http://onlinelibrary. wiley.com/doi/10.1002/wat2.1000/full>. Acesso em: 12 dez. 2017. 


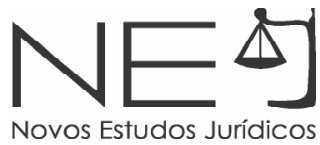

Há desafios a serem vencidos no âmbito da governança da água, em relação à coordenação de ações visando ao cumprimento das normas existentes sobre gestão e a qualidade da água. De um lado, é preciso buscar alternativas para o aumento da demanda da água e, de outro, alertar que a aplicação de tecnologias avançadas para o tratamento da água não prescinde da capacidade institucional das entidades envolvidas, de cumprir e fazer cumprir a legislação ambiental brasileira, no que concerne ao tripé da sustentabilidade: crescimento econômico, desenvolvimento social e prudência ambiental, conforme preconizado na Conferência das Nações Unidas sobre Meio Ambiente e Desenvolvimento - Rio/1992.

É importante salientar que o ordenamento jurídico brasileiro ainda não se ocupou desse tema de forma sistemática, não havendo previsão legal para o reúso não planejado indireto da água para fins potáveis (tampouco para o reúso direto com a mesma finalidade).

\section{CONSIDERAÇÕES ACERCA DO REÚSO DA ÁGUA}

A simples caracterização do reúso de água já enseja dificuldades. A rigor, a menção desse termo remete à atividade em que se tratam os esgotos de forma planejada e se utilizam os efluentes para finalidades menos exigentes quanto à qualidade, como é o caso do uso industrial, a lavagem de pisos, a rega de jardins e os usos agrícolas. Essa sistemática é relevante, e busca "minimizar os custos e os impactos ambientais associados a novos projetos"4. Todavia, não é a esse reúso que este artigo se refere.

O reúso indireto não planejado da água

(...) ocorre quando a água, utilizada em alguma atividade humana, é descarregada no meio ambiente e novamente utilizada a jusante, em sua forma diluída, de maneira não intencional e não controlada. Caminhando até o ponto de captação para o novo usuário, [....] está sujeita às ações naturais do ciclo hidrológico-diluição e autodepuração ${ }^{5}$.

\footnotetext{
4 HESPANHOL, Ivanildo. Um novo paradigma para a gestão de recursos hídricos. Revista Estudos Avançados. São Paulo, 2008, v. 22, n. 63, p. 131-158. ISSN 0103-4014. Disponível em: <http://dx.doi.org/10.1590/S010340142008000200009 >. Acesso em: 12 dez. 2017.

5 ZARED Filho, Kamel; GARCIA Luís Antônio Villaça de; PORTO Mônica Ferreira do Amaral; PORTO, Rubem La Laina. Reúso da água. Escola Politécnica da Universidade de São Paulo Departamento de Engenharia Hidráulica e Sanitária, 2007. Disponível em: <www.pha.poli.usp.br/LeArq.aspx?id_arq=2151>. Acesso em: 12 dez. 2017.
} 
O ponto crucial, nessa modalidade de reúso, é que ele ocorre de maneira não intencional e não controlada. Considerando a importância da água e as fragilidades detectadas nos mananciais, é relevante que se atente de modo realista para essa questão, buscando alternativas para que os efeitos deletérios causados nos corpos hídricos por essa prática possam ser minimizados e ao final solucionados. A rigor, o objeto da pesquisa deveria ser o reúso indireto dos efluentes das estações de tratamento de esgotos (ETE), de modo planejado. Para tanto, o pressuposto teórico deveria ser que todas as águas servidas seriam tratadas em processos específicos antes de seu lançamento em corpos hídricos. Todavia, essa não é a realidade brasileira, o que implica que se aborde a matéria a partir não apenas dos efluentes, mas dos esgotos lançados de forma difusa e in natura nos inúmeros corpos hídricos do país, provenientes de 1 . serviços de saneamento que coletam os esgotos, porém não os tratam, e 2. serviços que sequer coletam a totalidade dos esgotos nos municípios.

A consequência de haver mais de uma forma de despejar os esgotos sanitários em corpos hídricos (tratados e não tratados) consiste no comprometimento da qualidade dos rios e lagos, em desrespeito à legislação em vigor. Daí caberem considerações acerca 1. dos problemas relacionados à segurança do reúso não planejado indireto, o que demanda regras específicas para a captação das águas dos rios e lagos, em relação aos pontos de lançamento e 2. do exercício de uma governança da água na busca de soluções acordadas. A Resolução do Conselho Nacional do Meio Ambiente (CONAMA) n 430/2011, art. 4 ${ }^{\circ}$ VII conceitua os esgotos sanitários como "a denominação genérica para despejos líquidos residenciais, comerciais, águas de infiltração na rede coletora, os quais podem conter parcela de efluentes industriais e efluentes não domésticos".

O reúso de águas servidas pode ser realizado para fins potáveis e para fins não potáveis, sendo que o Brasil possui uma norma específica para a segunda categoria - fins não potáveis - Resolução do Conselho Nacional de Recursos Hídricos (CNRH) n 54/2005. Além disso, o reúso para fins potáveis pode ser direto ou indireto. $O$ reúso direto consiste na captação do efluente de uma estação de tratamento de esgoto (ETE) com a sua transferência imediata para uma estação de tratamento de água (ETA), sem que esse efluente seja diluído em um corpo hídrico. 
O reúso indireto não planejado para fins potáveis refere-se à captação de água em um corpo hídrico que tenha recebido efluentes (supostamente tratados) a uma certa distância a montante, sem qualquer planejamento. Esta segunda categoria é o objeto do presente artigo.

Cabe salientar, desde logo, que inexiste norma no Brasil que fixe algum critério para as duas modalidades de reúso com finalidades potáveis. O reúso direto não possui previsão legal. A Lei $n^{\circ} 11.445 / 2007$ determina que os efluentes das ETE sejam lançados "no meio ambiente". Dessa forma, essa modalidade de reúso não é praticada. Todavia, o reúso indireto não planejado, que tampouco possui regulamentação, é largamente adotado em uma relevante porção dos rios brasileiros.

Capta-se água para abastecimento humano em corpos hídricos que recebem esgotos de locais a montante, nem sempre tratados. Não há regra que estabeleça distâncias mínimas entre os pontos de lançamento e os pontos de captação. Essa lacuna enseja riscos à saúde pública e à biodiversidade, além de comprometer as atividades econômicas que dependem da qualidade da água, como é o caso do turismo e da pesca. Embora as tecnologias de tratamento de água e de esgotos estejam cada vez mais desenvolvidas, a ideia de primeiro poluir um corpo hídrico para depois tratar a água retirada não se coaduna com a estrutura normativa ambiental brasileira no que se refere à qualidade das águas. Essa questão se agrava na medida em que o tratamento de esgotos no país ainda se configura muito mais como planejamento a longo prazo e não como ação efetiva e sistemática, como deveria ser, em respeito à legislação em vigor.

Embora a Resolução CNRH no 54/2005 trate do reúso para fins não potáveis, os seus termos, nos tópicos mencionados, podem servir de ponto de partida para o estabelecimento de uma nova estrutura conceitual do reúso indireto não planejado para fins potáveis.

Essa norma define o reúso de água (para fins não potáveis) como uma "prática de racionalização e de conservação de recursos hídricos", conforme princípios estabelecidos na Agenda 21 e na Agenda 2030 - Objetivos do Desenvolvimento Sustentável (ODS) - evolução da Agenda 21 -, documento que prevê, em seu Objetivo 6, "assegurar a disponibilidade e gestão sustentável da água e 
Novos Estudos Jurídicos

saneamento para todas e todos, podendo [..] ser utilizada como instrumento para regular a oferta e a demanda de recursos hídricos".

O reúso de água para fins não potáveis consiste na "utilização de águas residuárias, como o esgoto, água descartada, efluentes líquidos de edificações, indústrias, agroindústrias e agropecuária, tratados ou não" (Resolução CNRH n ${ }^{\circ}$ $54 / 2005$, art. $2^{\circ}$, I). Note-se que a prática desse tipo de reúso não impõe, em si, o tratamento do efluente. Mas isso não significa que o seu tratamento esteja dispensado. Se o efluente de uma ETE, assim como qualquer outro, não estiver em conformidade com os padrões de lançamento fixados, e de acordo com a classe do corpo receptor, deve ser obrigatoriamente submetido a tratamento.

A falta de informações sobre tais despejos é extremamente prejudicial para a própria gestão dos recursos hídricos e para a adoção das necessárias medidas de melhoria da qualidade das águas. Essa situação, ainda não solucionada, demanda esforços na busca de caminhos que levem à regularização dos usos relacionados ao lançamento dos esgotos não tratados.

A Resolução CNRH no 54/2005, art. 2 , IV conceitua o reúso direto de água como o "uso planejado de água de reúso (para fins não potáveis), conduzida ao local de utilização, sem lançamento ou diluição prévia em corpos hídricos superficiais ou subterrâneos". Essa definição leva a crer, por outro lado, que o reúso indireto para finalidades potáveis seria então o uso do recurso mediante o lançamento ou a diluição prévia em corpos hídricos superficiais ou subterrâneos (devidamente tratados).

\section{AS ÁGUAS NA CONSTITUIÇÃO}

A Constituição Federal, ao tratar dos bens da União, e dos Estados (e do $D F)$, estabelece que "os lagos, rios e quaisquer correntes de água em terrenos de domínio da União, que banhem mais de um Estado, sirvam de limites com outros países, ou ainda se estendam a território estrangeiro ou dele provenham", pertencem à União (art. 20, III). Aos Estados e ao DF coube o domínio das "águas superficiais ou subterrâneas, fluentes, emergentes e em depósito, ressalvadas as decorrentes de obras da União" (art. 26, I). Essa regra constitucional tem como fator subjacente a caracterização da água como um bem público, por sua importância para a sociedade. O domínio, pois, significa a responsabilidade dos Entes 


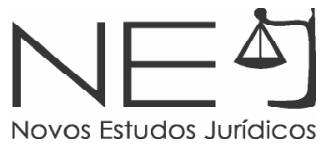

Federados pelo seu controle, gestão e proteção. É estabelecida a competência comum (material) da União, dos Estados, do DF e dos Municípios para "promover a melhoria das condições habitacionais e de saneamento básico" (CF/88, art. 23, IX). O parágrafo único do art. 23 prevê que "leis complementares fixarão normas para a cooperação entre a União e os Estados, o Distrito Federal e os Municípios, tendo em vista o equilíbrio do desenvolvimento e do bem-estar em âmbito nacional". Considerando que o domínio das águas é da União e dos Estados (e do DF), e que a titularidade dos serviços de saneamento básico - em que se enquadra o reúso indireto para fins potáveis - é dos Municípios, essa cooperação é relevante para definir papéis e responsabilidades no que diz respeito tanto ao planejamento como à implantação dos instrumentos das políticas de águas, com vistas à melhoria de sua qualidade e quantidade.

No que se refere às competências normativas voltadas às águas, a Constituição conferiu à União as atribuições de "instituir diretrizes para o desenvolvimento urbano, inclusive saneamento básico" (art.21,XX)ede"instituirsistema nacional degerenciamento de recursos hídricos e definir critérios de outorga de direitos de seu uso" (art. 21, XIX). A Lei $n^{\circ} 11.445 / 2007$, que dispõe sobre as Diretrizes Nacionais para o Saneamento Básico e a Lei n 9.433/1997, que instituiu a Política Nacional de Recursos Hídricos (PNRH) e seu Sistema Nacional de Gerenciamento, vieram regulamentar, respectivamente, os incisos mencionados, configurando duas políticas públicas intrinsecamente relacionadas, que, todavia, demandam grande esforço institucional em sua implementação com destaque para as soluções relacionadas à qualidade da água.

\section{QUALIDADE DA ÁGUA E PADRÕES AMBIENTAIS}

A PNMA (Lei n 6.938/1981) tem como principal objetivo (art. $2^{\circ}$ ):

(...) a preservação, melhoria e recuperação da qualidade ambiental propíciaà vida, visando assegurar, no país, condições ao desenvolvimento socioeconômico, aos interesses da segurança nacional e à proteção da dignidade da vida humana ecológico.

Ou seja, a "compatibilização do desenvolvimento econômico e social com a preservação da qualidade do meio ambiente e do equilíbrio" (art. 4 , I). Nota-se, 
no conteúdo desses dispositivos, a referência ao princípio do desenvolvimento sustentável, que trata da possibilidade de as gerações atuais atenderem às suas necessidades, sem comprometer a capacidade de as gerações futuras atenderem às suas, conforme estabelece o Relatório Brundtland, documento que serviu de base técnica para a Conferência das Nações Unidas sobre Meio Ambiente e Desenvolvimento de 1992 (Rio/92) ${ }^{6}$. O acesso à água potável vincula-se a essa formulação principiológica, na medida em que é condição essencial, tanto para a manutenção da vida como para a continuidade das atividades econômicas. O tema é atual e a Resolução da Assembleia Geral da ONU A/64/L.63/Rev.1, de 2010 declara:

(...) o direito à água potável e ao saneamento como um direito humano, essencial para a completa satisfação da vida e de todos os direitos humanos. Para tanto, conclama os Estados e as organizações internacionais para prover, em particular os países em desenvolvimento, de recursos financeiros, capacidade construtiva e transferência de tecnologia, por meio da assistência e cooperação internacional. ${ }^{7}$

Para alcançar o objetivo de preservar, melhorar e recuperar a qualidade ambiental, o marco regulatório ambiental fixado pela Lei $n^{\circ} 6.938 / 1981$ criou uma série de instrumentos, dentre os quais se destaca o "estabelecimento de padrões de qualidade ambiental". O termo "padrão" refere-se ao nível ou ao grau de qualidade de um elemento (substância ou produto) que é próprio ou adequado a determinado propósito ${ }^{8}$. A sua função é estabelecer parâmetros, geralmente representados por números, que indicam determinado estado de equilíbrio ambiental, permitindo-se que, no âmbito das atividades licenciadas, seja possível o lançamento de efluentes [...], em quantidades que sejam, em princípio, seguras do ponto de vista da qualidade ambiental ${ }^{9}$.

A respeito dos padrões relativos à água, a Resolução CONAMA n 357/2005 dispõe sobre a classificação dos corpos hídricos e as diretrizes ambientais para o seu enquadramento. A Resolução CONAMA n 430/2011, que alterou

6 COMISSÃO MUNDIAL SOBRE MEIO AMBIENTE E DESENVOLVIMENTO. Nosso futuro comum. 2. ed. Rio de Janeiro: FGV, 1991.

7 United Nations. A/ARES/64/291. Follow-up to paragraph 143 on human security of the 2005 World Summit Outcome. Disponível em: <http://www.un.org/en/ga/search/view_doc.asp?symbol =A/RES/64/291>. Acesso em: 12 dez. 2017.

8 MOREIRA, lara Verocai Dias. Vocabulário básico de meio ambiente. Rio de Janeiro: Fundação Estadual de Engenharia do Meio Ambiente (FEEMA), 1990. p. 149.

9 GRANZIERA, Maria Luiza Machado. Direito Ambiental. 4. ed. São Paulo: Atlas, 2015, pp. 410-411. 


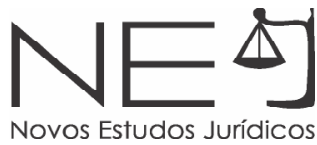

e complementou a Resolução CONAMA n 357/2005, estabelece as condições e as padrões de lançamento de efluentes. Aqui se insere outro instrumento de gestão, previsto na Lei $n^{\circ}$ 9.433/1997: o enquadramento dos corpos hídricos em classes de uso preponderante, intersecção entre as políticas ambientais e de recursos hídricos ${ }^{10}$, na medida em que tem por objeto a qualidade da água. Esses dois instrumentos, um da política ambiental, outro das políticas de águas, tratam de qualidade e são complementares, devendo ser estudados de forma conjunta.

Enquadrar um corpo hídrico em classes de uso preponderante significa estabelecer patamares de qualidade (metas) da água, relacionados com os usos pretendidos, seja para os lançamentos - padrões -, seja para os corpos receptores - classes. A Resolução CONAMA n 357/2005, art. $2^{\circ}$, IX define classe de qualidade como "o conjunto de condições e padrões de qualidade de água necessários ao atendimento dos usos preponderantes, atuais ou futuros". As águas doces são classificadas em Especial, Classe 1, Classe 2, Classe 3 e Classe 4 , sendo que cada uma delas se destina a usos preponderantes, em níveis de exigência decrescente, a partir da Classe Especial.

Segundo a Resolução CONAMA n 357/2005, art. 2 ${ }^{\circ}$ XX, o enquadramento consiste no "estabelecimento da meta ou objetivo de qualidade da água (classe) a ser, obrigatoriamente, alcançado ou mantido em um segmento de corpo de água, de acordo com os usos preponderantes pretendidos, ao longo do tempo".

Essa norma define, para o abastecimento para consumo humano, as seguintes condições, cabendo mencionar que não se prevê o aproveitamento da água para fins potáveis nos corpos de água de Classe 4: Classe especial: com desinfecção; Classe 1: após tratamento simplificado; Classe 2: após tratamento convencional; Classe 3: após tratamento convencional ou avançado.

No que se refere às regras aplicáveis ao lançamento dos efluentes das ETE, a Resolução CONAMA n 430/2011, art. 4 , VII, dispõe "esgotos sanitários" como "a denominação genérica para despejos líquidos residenciais, comerciais, águas

10 GRANZIERA, Maria Luiza Machado. Direito de Águas - Disciplina Jurídica das Águas Doces. 4. ed. São Paulo: Atlas, 2014, p. 98. 
Novos Estudos Jurídicos

de infiltração na rede coletora, os quais podem conter parcela de efluentes industriais e efluentes não domésticos".

Além disso, 0 art. $3^{\circ}$ dispõe que:

(...) os efluentes de qualquer fonte poluidora somente poderão ser lançados diretamente nos corpos receptores após o devido tratamento e desde que obedeçam às condições, padrões e exigências dispostos [na Resolução] e em outras normas aplicáveis.

A capacidade de suporte do corpo receptor é o "valor máximo de determinado poluente que o corpo hídrico pode receber, sem comprometer a qualidade da água e seus usos determinados pela classe de enquadramento" (art. $4^{\circ}$, VII). Além disso, os efluentes não poderão conferir ao corpo receptor características de qualidade em desacordo com as metas obrigatórias progressivas, intermediárias e final, do seu enquadramento, devendo as metas obrigatórias para corpos receptores ser estabelecidas por parâmetros específicos (Resolução CNRH n 91/2008). Já para os parâmetros não incluídos nas metas obrigatórias e na ausência de metas intermediárias progressivas, "os padrões de qualidade a serem obedecidos no corpo receptor são os que constam na classe na qual o corpo receptor estiver enquadrado" (art. $5^{\circ}$ ). A norma em vigor é suficientemente detalhada para deixar expressa a obrigação de tratamento dos efluentes antes de seu despejo nos corpos receptores.

O atendimento aos padrões fixados adquire especial importância na medida em que o lançamento de matérias ou energia em desacordo com os padrões ambientais estabelecidos caracteriza uma das hipóteses de ocorrência de poluição (Lei n 6.938/1981, art. 3ㅇ, III), o que remete à responsabilização civil, penal e administrativa do agente (CF/888, art. 225, § $\left.3^{\circ}\right)$.

A Resolução CONAMA n 430/2011, no art. 21, estabelece também condições e padrões específicos para efluentes de sistemas de tratamento de esgotos sanitários, devendo ser observado o seguinte:

pH entre 5 e 9;

temperatura: inferior a $40^{\circ} \mathrm{C}$, sendo que a variação de temperatura do corpo receptor não deverá exceder a $3^{\circ} \mathrm{C}$ no limite da zona de mistura; 


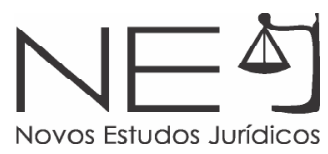

materiais sedimentáveis: até $1 \mathrm{~mL} / \mathrm{L}$ em teste de 1 hora em cone Inmhoff. Para o lançamento em lagos e lagoas, cuja velocidade de circulação seja praticamente nula, os materiais sedimentáveis deverão estar virtualmente ausentes;

demanda Bioquímica de Oxigênio-DBO 5 dias, $20^{\circ} \mathrm{C}$ : máximo de 120 $\mathrm{mg} / \mathrm{L}$. Este limite somente poderá ser ultrapassado no caso de efluente de sistema de tratamento com eficiência de remoção mínima de $60 \%$ de $\mathrm{DBO}$, ou mediante estudo de autodepuração do corpo hídrico que comprove atendimento às metas do enquadramento do corpo receptor;

substâncias solúveis em hexano (óleos e graxas) até $100 \mathrm{mg} / \mathrm{L}$; e

ausência de materiais flutuantes.

O art. 40, XIV da Resolução CONAMA n 430/2011, introduz um conceito que está estreitamente relacionado com os lançamentos de efluentes: a "zona de mistura", compreendida como:

(...) região do corpo receptor, estimada com base em modelos teóricos aceitos pelo órgão ambiental competente, que se estende do ponto de lançamento do efluente, e delimitada pela superfície em que é atingido o equilíbrio de mistura entre os parâmetros físicos e químicos, bem como o equilíbrio biológico do efluente e os do corpo receptor, sendo específica para cada parâmetro.

Nessas zonas são admitidas "concentrações de substâncias em desacordo com os padrões de qualidade estabelecidos para o corpo receptor, desde que não comprometam os usos previstos para o mesmo" (Resolução CONAMA n 430/2011, art. 13). Ou seja, uma parte do corpo hídrico no ponto de lançamento é destinada à diluição do efluente, devendo a qualidade fixada na legislação ser retomada a jusante, em uma distância a ser fixada a partir de estudos sobre a hidrologia do trecho do corpo hídrico. "A extensão e as concentrações de substâncias na zona de mistura deverão ser objeto de estudo, quando determinado pelo órgão ambiental competente, às expensas do empreendedor responsável pelo lançamento".

Segundo a norma, os modelos teóricos que definem a zona de mistura devem ser aceitos pelo "órgão ambiental competente", isto é, o órgão ou a entidade responsável pelo licenciamento do empreendimento que lançará efluentes no 
Novos Estudos Jurídicos

corpo hídrico. Pressupõe-se, pois, que exista uma atividade licenciada, em que o órgão ambiental não apenas está ciente dos parâmetros relacionados com a zona de mistura apresentados pelo empreendedor, como está de acordo com eles.

Nessa linha de raciocínio, a disposição final dos esgotos sanitários devidamente tratados é uma condição para que se proceda ao reúso indireto desses efluentes, lançados nos corpos de água. Devem ser observados os padrões de lançamento, assim como a classe do corpo hídrico (receptor) em que é lançado o efluente, considerando a zona de mistura. Em um segundo momento, a água captada no corpo hídrico será conduzida a uma Estação de Tratamento de Água (ETA), em observância dos padrões de qualidade e de potabilidade, para então ser distribuída aos serviços de abastecimento de água, constituídos pelas atividades, infraestruturas e instalações necessárias ao abastecimento público de água potável, desde a captação até as ligações prediais dos usuários e dos respectivos instrumentos de medição (Lei n 11.445/2007, art. 3º, I, a).

O fundamento legal dessa sistemática encontra-se na Lei n 6.938/1981, que inclui as águas superficiais e subterrâneas no universo dos recursos ambientais, sujeitando-as à proteção estabelecida no art. 225 da Constituição, que impõe ao Poder Público e à coletividade o dever de "defender o meio ambiente e preserválo para as presentes e futuras gerações.

\section{AS SITUAÇÕES IRREGULARES}

As considerações efetuadas no item anterior acerca das normas sobre qualidade, padrões e enquadramento de corpos hídricos e zona de mistura referem-se aos casos em que o município (titular do serviço) coleta e trata os seus esgotos, em uma ETE licenciada e, portanto, enquadrada nas regras estabelecidas. Nesse caso, o foco da discussão seria relativo ao planejamento do reúso indireto no âmbito do licenciamento ambiental, conforme previsto na Resolução CONAMA n 430/2011, art. 13, parágrafo único. Todavia, uma porção relevante dos esgotos produzidos no país não são conduzidos a uma ETE. Há casos em que o serviço de saneamento coleta os esgotos e os lança sem tratamento. $E$ outros em que não há sequer coleta. Esses lançamentos, de caráter difuso ou não, fazem parte do universo das situações irregulares. 


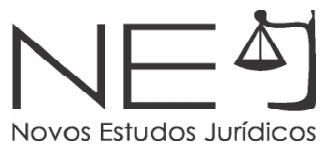

Se não há ETE no sistema de esgotamento sanitário, não há empreendimento a ser licenciado. Consequentemente, não haverá qualquer estudo que possa verificar a extensão e as concentrações de substâncias na zona de mistura, entre outras condições. Esses despejos irregulares, que descumprem toda a normativa que permitiria um reúso planejado da água para fins potáveis, não são cadastrados, não possuem outorga de lançamento e tampouco são licenciados. São apenas elementos causadores da poluição e da contaminação hídrica.

Apenas nas bacias hidrográficas em que está implementada a cobrança pelo uso de recursos hídricos esses usos em desconformidade vêm sendo considerados. Isso é possível quando o órgão ou a entidade gestora de recursos hídricos define sistemas de autodeclaração de uso, sem imposição de penalidades por certo lapso de tempo, como um passo intermediário para a respectiva e necessária regularização, permitindo que esses lançamentos, sujeitos à cobrança, constem nos sistemas de informação, com a perspectiva de uma regularização futura.

Sem a aplicação desses mecanismos, os lançamentos de esgotos sem tratamento são "ignorados", e sequer submetem-se ao sistema de cobrança, o que não deixa de afrontar o princípio constitucional da isonomia. E, claro, permanecem sob a característica de reúso não planejado.

Esses casos impõem outro tipo de solução, já que a estrutura normativa em vigor sobre qualidade de água, padrões, enquadramento e licenciamento ambiental não os alcança como deveria acontecer. É preciso buscar formulações diversas, em políticas adotadas de forma mais robusta, com uma aplicação efetiva do sistema de articulação institucional e governança contida nas políticas de recursos hídricos e, sobretudo, na atuação dos comitês de bacia hidrográfica para vislumbrar alguma resposta para o problema.

\section{POLÍTICAS DE RECURSOS HÍDRICOS}

A Lei $n^{\circ}$ 9.433/1997, em seu art. $1^{\circ}$, estabelece, entre os fundamentos da Política Nacional de Recursos Hídricos (PNRH), que "a água é um recurso natural limitado, dotado de valor econômico". Na medida em que a demanda pode exceder a disponibilidade hídrica, é imperioso racionalizar o uso, servindo a 
Novos Estudos Jurídicos

cobrança como instrumento, entre outros objetivos, do reconhecimento do valor econômico e do incentivo a essa racionalização (art. 19, I e II). Tal dispositivo se coaduna com o art. $4^{\circ}$ da Lei n 6.938/1981, que determina "caber, ao usuário, a contribuição pela utilização de recursos ambientais com fins econômicos". O princípio usuário pagador é o fundamento da cobrança pelo uso de recursos hídricos em sintonia com a política ambiental. Embora a água possua um valor econômico, é também essencial à vida. A lei prevê que, "em situações de escassez, a prioridade é o consumo humano e a dessedentação de animais" (art. $1^{\circ}$, III). Essa disposição, de cunho emergencial, significa que, em tempos normais, a gestão das águas deve proporcionar o "uso múltiplo" (art. $\left.1^{\circ}, \mathrm{IV}\right)$, considerando-se, sempre, que o "recurso é limitado" (art. $1^{\circ}$, II).

Tratando especificamente da gestão, o art. 10 ${ }^{\circ}$ V, da Lei no 9.433/1997, estabelece que a bacia hidrográfica é a "unidade territorial para implementação da Política Nacional de Recursos Hídricos e atuação do Sistema Nacional de Gerenciamento de Recursos Hídricos". Além disso, "a gestão dos recursos hídricos deve ser descentralizada e contar com a participação do Poder Público, dos usuários e das comunidades" (art. 1º, VI).

Como arcabouço institucional para fazer frente a essa política pública, foram criados os comitês de bacias hidrográficas e os conselhos de recursos hídricos, em âmbito federal e dos Estados, com funções relacionadas à articulação. O art. $3^{\circ}$ da Lei n 9.433/1997 expressamente menciona "a articulação do planejamento de recursos hídricos com o dos setores usuários e com os planejamentos regional, estadual e nacional" e "a articulação da gestão de recursos hídricos com a do uso do solo" como diretrizes da PNRH.

Em termos de atuação dos órgãos colegiados, tem-se que os comitês propõem, entre outros itens relativos à gestão, o enquadramento dos corpos hídricos, as prioridades para outorga de direito de uso de recursos hídricos e os valores e mecanismos de cobrança, cabendo aos respectivos Conselhos aprová-los. Já o plano de aplicação desses valores consiste em atribuição dos comitês. A seleção de projetos e obras específicos condiciona-se à aplicação de critérios objetivos em processos administrativos próprios, tendo como base as prioridades apontadas no 
plano de recursos hídricos. A dimensão da gestão descentralizada e participativa decorre do poder de decisão (motivada) dos comitês dos quais participam, além dos entes detentores do domínio da água (União, Estados e DF), os Municípios, a sociedade civil e os usuários. Tal modelo de gestão estabelece um novo paradigma. Antes da edição das políticas de recursos hídricos, o usuário reportava-se somente ao Poder Público, no que se refere ao uso da água, por meio das atividades de comando e controle decorrentes do exercício do poder de polícia.

No sistema vigente, a obrigação de adequar-se às normas permanece perante o Poder Público, mas ocorre em um cenário em que todos mantêm (ou deveriam manter) compromissos recíprocos, no âmbito da bacia, em um sistema que permite o exercício da governança como forma de estabelecer acordos factíveis entre os diversos atores, com base no princípio da boa-fé. Trata-se de um compromisso ético perante todos os demais atores que desenvolvem atividades na mesma bacia e que nela têm interesse, aprofundando a ideia de recurso hídrico compartilhado (no que diz respeito ao interesse sobre o bem) do qual todos dependem para os mais variados fins. E isso se aplica inclusive aos serviços de saneamento básico.

A questão do reúso indireto não planejado deve ser inserida nesse universo, na medida em que o aumento da demanda exige uma mudança de comportamento em relação ao uso racional da água, prática que se insere como uma das alternativas de proteção e produção do recurso. Para instituir o reúso direto planejado com finalidades de abastecimento humano, será necessário um grande esforço para recuperar a qualidade dos mananciais, cabendo aos comitês de bacia hidrográfica promover as necessárias discussões relacionadas com essa questão, além da possibilidade de uma atuação específica dos órgãos e das entidades ambientais e também dos municípios, no que concerne aos despejos irregulares.

A Resolução CNRH n 54/2005, voltada ao reúso não potável, vem servir de referência ao tratamento a ser conferido ao reúso indireto para fins potáveis, na medida em que o seu art. $8^{\circ}$ estabelece que os Comitês deverão:

(...) considerar, na proposição dos mecanismos de cobrança e aplicação dos recursos da cobrança, a criação de incentivos para a prática de reúso, 2. integrar, no âmbito do Plano de Recursos Hídricos da Bacia, 
a prática de reúso com as ações de saneamento ambiental e de uso e ocupação do solo na bacia hidrográfica.

Os Sistemas de Informações sobre Recursos Hídricos deverão incorporar, organizar e tornar disponíveis as informações sobre as práticas de reúso necessárias para o gerenciamento dos recursos hídricos (art. $7^{\circ}$ ).

No que se refere ao cadastro de usuários, a resolução em tela, no art. 9, dispõe que o reúso de água deverá ser informado, quando requerido ao órgão gestor, para fins de cadastro, devendo contemplar, no mínimo:

(...) identificação do produtor, distribuidor ou usuário; 2. localização geográfica da origem e destinação da água de reúso; 3. especificação da finalidade da produção e do reúso de água; 4. vazão e volume diário de água de reúso produzida, distribuída ou utilizada.

Além disso, o art. 10 dispõe que "deverão ser incentivados e promovidos programas de capacitação, mobilização social e informação quanto à sustentabilidade do reúso, em especial os aspectos sanitários e ambientais".

Tais regras, ainda que aplicáveis ao reúso de água para finalidades não potáveis, inserem o reúso na ótica da gestão de recursos hídricos e da sustentabilidade ambiental, da mesma forma que deveria ser considerado o reúso indireto para fins potáveis. Todavia, a norma se ocupa dos empreendimentos revestidos de legalidade, o que não ocorre com uma parte dos despejos dos serviços de saneamento, quando não tratam os esgotos.

Daí a proposta de dar relevância para essa questão, deixando claros impactos na qualidade das águas das bacias e, consequentemente, na saúde pública ${ }^{11} \mathrm{e}$ no meio ambiente. É necessário caracterizar de forma muito clara as situações de despejo irregular de esgotos sanitários sem tratamento e as captações para fins potáveis como reúso indireto, na linha da Resolução CNRH n 54/2005, o que pode ser um primeiro passo para equacionar a questão no âmbito do planejamento dos recursos hídricos.

11 LIBÂNIO, Paulo Augusto Cunha; CHERNICHARO, Carlos Augusto de Lemos; NASCIMENTO, Nilo de Oliveira. A dimensão da qualidade de água: avaliação da relação entre indicadores sociais, de disponibilidade hídrica, de saneamento e de saúde pública. Engenharia Sanitária e Ambiental, Rio de Janeiro, jul/set 2005, v. 10, n. 3. Disponível em: <http://dx.doi.org/10.1590/S1413-41522005000300006>. Acesso em: 12 dez. 2017. 


\section{PLANOS DE RECURSOS HÍDRICOS}

Os planos de recursos hídricos de bacias hidrográficas são instrumentos técnicos aprovados pelos comitês, que fornecem uma fotografia da região, indicando cenários para o futuro, com vistas à sua gestão. Destacam-se os seguintes itens, a serem incorporados ao conteúdo desses documentos:

1. diagnóstico da situação atual dos recursos hídricos; balanço entre disponibilidades e demandas futuras dos recursos hídricos, em quantidade e qualidade, com identificação de conflitos potenciais;

2. metas de racionalização de uso, aumento da quantidade e melhoria da qualidade dos recursos hídricos disponíveis;

3. medidas a serem tomadas, programas a serem desenvolvidos e projetos a serem implantados, para o atendimento das metas previstas;

4. planos de utilização prioritária e propostas de enquadramento dos corpos d'água em classe de uso preponderante;

5. programas anuais e plurianuais de recuperação, proteção, conservação e utilização dos recursos hídricos da baçia hidrográfica correspondente, inclusive com especificações dos recursos financeiros necessários.

No conteúdo dos planos enquadram-se as questões relacionadas com o saneamento básico dos municípios, em relação às metas de qualidade, às medidas, aos programas e aos projetos a serem adotados para o alcance das metas, as propostas de enquadramento e os programas anuais de recuperação, proteção, conservação e utilização dos recursos hídricos.

Segundo a Resolução CNRH no 54/2005, art. 6, os "Planos de Recursos Hídricos deverão contemplar, entre os estudos e alternativas, a utilização de águas de reúso e seus efeitos sobre a disponibilidade hídrica", devendo ser observadas as metas de: 1 . racionalização de uso; 2. aumento da quantidade; e 3. melhoria da qualidade dos recursos hídricos disponíveis.

A rigor, o plano poderia fornecer parâmetros para a fixação de zonas de mistura a serem observados no processo de licenciamento ambiental. Todavia, 
nem sempre esses documentos possuem escala suficiente para abordar tal detalhe, salvo para os rios mais importantes e mais impactados pelos despejos. Seria mais adequado abordar o tema nos planos de saneamento básico, cujo conteúdo limita-se ao território de um único município.

Se nem os planos de bacia hidrográfica nem os de saneamento básico fornecem essas informações, a fixação de zonas de mistura fica relegada unicamente aos órgãos e às entidades licenciadoras. O que não é suficiente, pois essa seria uma solução apenas para as ETE e os sistemas licenciados. Os sistemas de saneamento básico que coletam esgotos e não os tratam ou sequer os coletam deixam em aberto quaisquer soluções normativas para os casos de despejo de esgoto in natura, no que se refere à zona de mistura.

\section{DIRETRIZES GERAIS PARA O SANEAMENTO BÁSICO}

O saneamento é serviço público - atividade sob a responsabilidade do Poder Público, com o fim de atender a uma necessidade de interesse geral. A não prestação, a má prestação, ou ainda a prestação insuficiente do serviço, podem causar danos à saúde, ao patrimônio e ao meio ambiente. Caberá aqui aprofundar o abastecimento de água potável e o esgotamento sanitário.

O abastecimento de água potável constitui-se por atividades, infraestruturas e instalações voltadas à captação em corpo hídrico superficial ou subterrâneo, seu tratamento, a reservação e a adução da água até os pontos de ligação (Lei $n^{\circ} 11.445 / 2007$, art. 30 $3^{\circ}$ a). Para tanto, são necessários mananciais protegidos e uma qualidade compatível com os padrões legais de potabilidade, para evitar doenças veiculadas pela água e riscos de contaminação.

O Decreto $n^{\circ} 5.440 / 2005$ estabelece definições e procedimentos sobre o controle de qualidade da água de sistemas de abastecimento e institui mecanismos e instrumentos para divulgação de informação ao consumidor sobre a qualidade da água para consumo humano.

A Portaria MS no 2.914/2011 dispõe sobre os procedimentos de controle e de vigilância da qualidade da água para consumo humano e seu padrão de potabilidade. Se aplicadas as normas vigentes sobre potabilidade, utilizando-se 
de tecnologias capazes de tratar a água de modo a atender a essas normas, haverá água potável. Entretanto, a aplicação de tecnologias de ponta não dispensa a proteção ambiental dos corpos hídricos e das atividades econômicas de dependem de água com melhor qualidade.

O esgotamento sanitário constitui-se pelas "atividades, infraestruturas e instalações operacionais de coleta, transporte, tratamento e disposição final adequados do esgoto, desde as ligações prediais até o seu lançamento final no meio ambiente" (Lei $n^{\circ} 11.445 / 2007$, art. $3^{\circ}$, I, b). Aqui, uma questão a colocar sobre o reúso direto para fins potáveis. Lançar no meio ambiente, como dispõe a norma sobre saneamento, não significa lançar em sistema de abastecimento de água para consumo humano, definido pelo Decreto $n^{\circ}$ 5.440/2005 como a "instalação composta por conjunto de obras civis, materiais e equipamentos, destinada à produção e à distribuição canalizada de água potável para populações".

A conceituação da estação de tratamento de água (ETA) conferida pelo decreto mencionado não se caracteriza como "meio ambiente", que é a destinação legalmente prevista pela Lei $n^{\circ} 11.445 / 2007$, para o esgoto, após o tratamento. Não há, pois, previsão legal para a ligação de efluentes na rede de distribuição de água, o que significa que não há previsão legal para o reúso direto para o consumo humano no país.

Segundo o art. 19 da Lei no 11.445/2007, a prestação de serviços observará plano. O planejamento consiste em uma das obrigações do titular dos serviços (municípios) previstas na lei e refere-se ao estudo e à fixação das diretrizes e das metas que deverão orientar determinadas ações. É preciso planejar como será feita a prestação dos serviços, de acordo com as características e necessidades locais.

O planejamento também corresponde ao princípio da eficiência, previsto no art. $37 \mathrm{da} C F / 88$, pois direciona o uso dos recursos públicos de uma forma racional. A Lei $n^{\circ}$ 11.445/2007 também menciona expressamente os princípios da "eficiência" e da "sustentabilidade econômica" como fundamentos da prestação dos serviços de saneamento básico (art. $\left.2^{\circ}, \mathrm{VII}\right)$. 
O conteúdo mínimo estabelecido para os planos municipais de saneamento básico inclui a elaboração de "um diagnóstico da situação e de seus impactos nas condições de vida, utilizando sistema de indicadores sanitários, epidemiológicos, ambientais e socioeconômicos e apontando as causas das deficiências detectadas" (Lei no 11.445/2007, art. 19, I). É necessário o conhecimento da situação ambiental, de saúde pública, social e econômica do Município, com destaque para os impactos dos serviços de saneamento nesses indicadores. Ainda na linha de projetos e ações a serem propostos, a lei prevê a indicação, no plano de saneamento, de ações para emergências e contingências. Merece destaque o item que prevê, como conteúdo mínimo dos planos de saneamento, os "mecanismos e procedimentos para a avaliação sistemática da eficiência e eficácia das ações programadas" (Lei no 11.445/07, art. 19, V). Trata-se de um avanço na legislação, pois fica estabelecido, desde logo, que o conteúdo do plano deve ser cumprido, com a indicação dos respectivos mecanismos de aferição.

A partir daí, cabe traçar no plano os objetivos e as metas de curto, médio e longo prazos para a universalização, um dos pilares das Diretrizes Nacionais para o Saneamento Básico. Devem então ser indicados os programas, os projetos e as ações necessárias para atingi-los, identificando-se as possíveis fontes de financiamento, admitidas soluções graduais e progressivas. Deve ser também observada a compatibilidade com os respectivos Planos Plurianuais demais e planos setoriais (em que se inclui o plano de recursos hídricos da respectiva bacia hidrográfica).

A poluição e a contaminação dos corpos de água decorrentes do reúso indireto não planejado para finalidades potáveis devem estar explicitadas nesses programas, projetos e ações necessárias à universalização dos serviços, previstos nos planos de saneamento básico. Lembrando que o princípio da universalização dos serviços consiste na ampliação progressiva do acesso de todos os domicílios ocupados ao saneamento básico (Lei $\mathrm{n}^{\circ}$ 11.445/2007, art. $3^{\circ}$, III), conforme as metas estabelecidas, a totalidade da população deve ter acesso a eles, incluindo o tratamento dos esgotos, de acordo com os cronogramas estabelecidos. 
Considerando a fase de implementação do plano municipal de saneamento básico, a articulação é um tema fundamental, pois é preciso integrar as decisões sobre vários aspectos, que, na prática, acabam por impactar o mesmo território. Nos termos da Lei $n^{\circ} 11.445 / 2007$, art. $2^{\circ}$, VI, os serviços de saneamento serão prestados com base na:

(...) articulação com as políticas de desenvolvimento urbano e regional, de habitação, de combate à pobreza e de sua erradicação, de proteção ambiental, de promoção da saúde e outras de relevante interesse social voltadas para a melhoria da qualidade de vida.

A lei de saneamento condiciona explicitamente o planejamento municipal a um plano de caráter regional, qual seja, o da bacia hidrográfica em que se localiza o Município. A conexão dos planos de recursos hídricos com os planos municipais de saneamento básico, dessa forma, não pode ser desconsiderada, já que somente o conjunto de seus conteúdos fornece as informações complementares e as propostas necessárias à gestão efetiva dos recursos hídricos, considerando também a proteção ambiental envolvida.

A área de estudo do plano de saneamento básico está contida no espaço territorial objeto do plano de bacia hidrográfica, o que fundamenta a necessidade de os Municípios considerarem, em seu planejamento, fatores externos ao seu território. A relação do Município com a bacia hidrográfica em que está localizado é, pois, um fator estratégico para a busca de soluções para o problema apresentado, cabendo introduzir, nos planos municipais de saneamento básico, o tema do reúso indireto não planejado, realidade a ser explicitada nesses documentos, já que é causa relevante da poluição e da degradação ambiental.

Além disso, é preciso fixar parâmetros para o reúso indireto no território do município. Os planos, como documentos técnicos com uma escala bem menor que os planos de bacia, podem abarcar essa discussão a ser também articulada pelos comitês de bacia hidrográfica.

Assim, seria possível ampliar o conhecimento dos pontos de despejo irregular, buscando formas de sua regularização, já que estabelecer regras para elas carece de viabilidade, conforme exposto. Essas questões fazem parte das atribuições 
dos comitês, a partir de iniciativa dos municípios, que compartilham a mesma bacia e são ali representados. Outro ponto a destacar na lei de saneamento consiste na obrigação de o titular estabelecer mecanismos de controle social (Lei $n^{\circ} 11.445 / 2007$, art. $3^{\circ}$, IV), definido como:

(...) conjunto de mecanismos e procedimentos que garantem à sociedade informações, representações técnicas e participações nos processos de formulação de políticas, de planejamento e de avaliação relacionados aos serviços públicos de saneamento básico.

No que se refere ao controle social, o art. $19, \S 5^{\circ}$ da lei determina a ampla divulgação das propostas dos planos de saneamento básico e dos estudos que as fundamentem, inclusive com a realização de audiências ou consultas públicas. A participação da sociedade é de fundamental importância, pois muitas informações acerca de problemas pontuais, às vezes de fácil solução, somente aparecem nas oficinas e nas reuniões realizadas com a população, quando da elaboração dos planos municipais de saneamento básico.

\section{GOVERNANÇA NO ÂMBITO DO SANEAMENTO E DA GESTÃO DE ÁGUAS}

O conceito de governança, nos processos decisórios que incluem a implementação dos planos de recursos hídricos das bacias hidrográficas e dos planos municipais de saneamento básico, refere-se a "padrões de articulação e cooperação entre atores sociais e políticos e arranjos institucionais que coordenam e regulam transações dentro e através das fronteiras do sistema econômico"12.

Segundo o Banco Mundial, em seu documento Governance and Development, de 1992, a definição geral de governança é "o exercício da autoridade, controle, administração, poder de governo". Trata-se da

(...) maneira pela qual o poder é exercido na administração dos recursos sociais e econômicos de um país visando ao desenvolvimento, implicando ainda a capacidade dos governos de planejar, formular e implementar políticas e cumprir funções ${ }^{13}$.

12 SANTOS, Maria Helena de Castro. Governabilidade, governança e democracia: criação de capacidade governativa e relações Executivo-Legislativo no Brasil pós-Constituinte. DADOS - Revista de Ciências Sociais. Rio de Janeiro, 1997 , v. 40, n. 3, p. 4. Disponível em: <http://www.scielo.br/scielo.php?script=sci_arttext\&pid=S0011$52581997000300003 \&$ Ing=pt\&nrm=iso >. Acesso em: 12 dez. 2017.

13 GONÇALVES, Alcindo. O conceito de governança. XIV Congresso Nacional CONPEDI, Fortaleza, 2005, p. 1. Disponível em: <http://www.egov.ufsc.br/portal/sites/default/files/conceito_de_governanca.pdf>. Acesso em: 12 dez. 2017. 
Destacam-se duas questões no que concerne à governança ${ }^{14}$. Em primeiro lugar, "uma 'boa' governança é um requisito fundamental para um desenvolvimento sustentado, que incorpora ao crescimento econômico a equidade social e também os direitos humanos". Em segundo lugar,

(...) os procedimentos e práticas governamentais na consecução de suas metas adquire relevância, incluindo aspectos como o formato institucional do processo decisório, a articulação público-privado na formulação de políticas ou ainda a abertura maior ou menor para a participação dos setores interessados ou de distintas esferas de poder.

Pode-se afirmar que a governança aplicada aos processos decisórios relativos aos serviços de saneamento básico diz respeito, inicialmente, à implementação dos planos municipais de saneamento básico, instrumento chave para que se desencadeiem todas as ações necessárias para modificar a situação atual dos municípios, introduzindo uma nova forma de gestão dos serviços. Essa alteração passa pela capacidade de todos os atores em estabelecer uma articulação permanente entre si no que se refere tanto à formulação do plano e à fixação das metas, como à sua implementação, na busca de recursos e projetos que possam responder às necessidades locais. Segundo a Organização para a Cooperação e Desenvolvimento Económico (OCDE):

(...) lidar com os desafios atuais e futuros requer políticas públicas mais robustas, visando objetivos mensuráveis de acordo com calendários pré-determinados e à escala adequada, baseadas numa clara atribuição de competências a todas as autoridades responsáveis e sujeitas a monitorização e avaliação periódicas ${ }^{15}$.

A elaboração e a implementação dos planos municipais de saneamento básico deveriam constituir um desafio a ser plenamente cumprido pelos poderes públicos. Os lançamentos de esgotos sanitários sem tratamento em corpos hídricas, relativos a estruturas não licenciadas, e que, portanto, ficam fora da singela estrutura normativa que trata do reúso indireto da água não planejado, não podem e não devem ser ignorados. Já se mencionou neste artigo que não basta captar água de um corpo hídrico poluído, aplicar tecnologias sofisticadas para o atendimento aos padrões de potabilidade e distribuí-las aos usuários.

14 WORLD BANK. Governance and Development, 1992. Disponível em: <http://documents.worldbank.org/curated/ en/604951468739447676/pdf/multi-page.pdf>. Acesso em: 12 dez. 2017.

15 ORGANIZAÇÃO PARA A COOPERAÇÃO E DESENVOLVIMENTO ECONÔMICO (OCDE). Princípios da OCDE para a Governança da Água. OCDE, 2015. 
Os rios não podem servir de condutores de esgotos, até o próximo ponto de captação. É necessário que ele desempenhe sua função ambiental de habitat e a função econômica de permitir atividades que garantam o sustento das comunidades. Isso sem falar na paisagem e nas possibilidades de turismo que podem garantir maior circulação de riquezas.

De outro lado, conhece-se perfeitamente a dificuldade que existe na aplicação de recursos financeiros ao saneamento básico, incluindo o tratamento dos esgotos. Mas isso não pode ser uma razão plausível para que a situação permaneça como se encontra.

O problema é originado nos municípios, mas gera impactos a jusante da bacia hidrográfica. Os comitês das bacias hidrográficas com problemas de qualidade de água devem exercer, no âmbito da governança para a qual foram instituídos, uma articulação direta com os municípios da bacia - titulares dos serviços de saneamento - e responsáveis pelo tratamento dos esgotos. A ideia é verificar a real situação de cada município à luz dos lançamentos de esgoto, por meio da análise dos planos de saneamento básico, que por sua vez já devem ter sido discutidos no âmbito do município, quando de sua elaboração e processo de aprovação.

Feita a articulação com os municípios, e conhecidos aqueles cujos lançamentos são mais deletérios para a qualidade de toda a bacia hidrográfica, o comitê poderá conduzir os respectivos processos de regularização como prioridade, no âmbito do conteúdo do plano de bacia hidrográfica. Cada caso, devidamente descrito no plano municipal de saneamento básico, acompanhado do respectivo estudo de viabilidade técnica, ambiental e econômica do projeto, poderia ser inserido no plano de investimentos da bacia, como prioridade, devidamente aprovado pelo comitê. Essa seria uma forma de regularizar os lançamentos, adequando-os ao ordenamento jurídico vigente.

Essa sistemática não necessita de qualquer norma nova. A legislação em vigor permite esse tipo de articulação e discussão. Ademais, considerando que se trata de uma alternativa a ser negociada, existem maiores perspectivas de cumprimento, na linha do que se disse acerca dos compromissos éticos que podem ser assumidos no âmbito desses colegiados. 
A análise do arcabouço jurídico brasileiro acerca da qualidade da água aponta duas situações distintas, relativas ao lançamento de efluentes domésticos em corpos de água. A primeira refere-se aos esgotos tratados em sistemas próprios, objeto de licenciamento ambiental, em que o órgão ou a entidade ambiental estabelece as condições de lançamento de acordo com a lei, definindo como deve ser a zona de mistura. Essa situação garante minimamente que o serviço de esgotamento sanitário não cause poluição nos corpos hídricos, o que permite que estes se mantenham em condições adequadas, inclusive para servir como mananciais. Nesses casos há, em princípio, um reúso indireto, porém planejado. Na sistemática atual, somente o órgão licenciador fixa os limites e os parâmetros da zona de mistura, no âmbito dos processos de licenciamento ambiental.

A segunda situação refere-se aos casos em que os esgotos são lançados muitas vezes de forma difusa e sem tratamento e, por óbvio, sem a devida licença ambiental, o que significa que não há parâmetros de concepção de projeto nem da zona de mistura, cabendo o controle sobre os efeitos desses efluentes nos rios e lagos aos órgãos ambientais, sem que esses casos estejam contidos no bojo dos instrumentos de gestão ambiental e de recursos hídricos. Essa sistemática compromete, em um primeiro momento, a qualidade das águas e, em um segundo momento, a segurança nas captações realizadas para fins potáveis, independentemente das tecnologias existentes de purificação e atingimento dos padrões de potabilidade.

Buscando uma solução efetiva para essa questão, vislumbra-se a necessidade de uma efetiva articulação entre os planos municipais de saneamento básico e o plano de recursos hídricos da bacia hidrográfica em que se localizam os municípios. Os planos de saneamento, por sua escala mais detalhada, podem indicar os problemas relacionados com os despejos de esgoto in natura: localização, problemas com a rede, lançamentos na rede pluvial, monitoramento da qualidade do rio a jusante, e outras informações que indiquem a realidade local.

Articulando esses dois planos, seria possível verificar quais os municípios cujos despejos de esgotos in natura impactam de forma mais negativa a bacia hidrográfica. 
Essa informação, articulada pelo comitê de bacia hidrográfica, e com a participação dos municípios, poderia abrir espaço para o exercício da governança, levando a uma decisão negociada sobre a ordem de prioridade dos projetos de tratamento de esgotos, considerando o impacto dos lançamentos nas captações mais próximas e também, em um enfoque mais ampliado, os impactos negativos para toda a bacia. A partir dessa discussão, esses projetos seriam incluídos paulatinamente no plano de aplicação dos recursos disponíveis para a bacia hidrográfica, como é o caso do produto da cobrança pelo uso de recursos hídricos.

A importância de introduzir e enfrentar a questão dos lançamentos irregulares em um universo institucional e objeto de governança parece ser uma estratégia adequada para construir uma segurança hídrica consistente, na medida em que esses usos da água passam a ser explicitados não apenas no âmbito dos municípios, mas também da bacia hidrográfica, deixando claro que a realidade atual não beneficia nem os prestadores de serviços de água, nem a população, nem a saúde, nem o meio ambiente.

A governança da água pode contribuir significativamente para a concepção e implementação de tais políticas, envolvendo uma responsabilidade partilhada entre diferentes níveis de governo, sociedade civil, empresas e o mais alargado leque de partes interessadas que tenham um papel importante a desempenhar ao lado dos decisores políticos para que se colham os benefícios econômicos, sociais e ambientais de uma boa governança da água ${ }^{16}$.

Trata-se de um desafio, porém totalmente convergente com a implantação das políticas de recursos hídricos, meio ambiente e saneamento básico, considerando a necessidade de dar relevância à governança que faz parte e dá fundamento à existência dos comitês de bacia hidrográfica. Dificuldades existem. Se não fosse assim, o Estado não dispenderia recursos na criação e na manutenção de órgãos e entidades cujas atribuições convergem para a gestão ambiental e de recursos hídricos. Nesse sentido, é de fundamental importância lembrar a necessidade de garantir-se uma governança saudável no âmbito dos sistemas de gestão ambiental e de águas, pois os temas se relacionam intrinsecamente, na medida em que as bacias hidrográficas são muitas vezes formadas por rios de domínios distintos, e

16 OCDE. Princípios da OCDE para a Governança da Água. OCDE, 2015. 


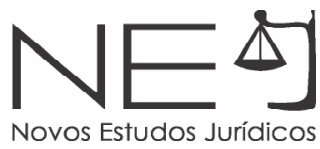

os municípios localizados nas bacias também possuem funções estratégicas no que se refere às águas, embora não detenham o seu domínio.

\section{REFERÊNCIAS DAS FONTES CITADAS}

AGÊNCIA NACIONAL DE ÁGUAS. Atlas Brasil - Abastecimento Urbano de Água. Brasília, 2015. Disponível em: <http://atlas.ana.gov.br/Atlas/forms/Home.aspx. Acesso em: 12 dez. 2017>.

BRASIL.Constituição (1988). Disponível em: <http://www.planalto.gov.br/ccivil_03/constituicao/ constituicaocompilado.htm>. Acesso em: 12 dez. 2017.

BRASIL. Decreto $\mathbf{n}^{\circ}$ 5.440, de 4 de maio de 2005. Disponível em: <http://www.planalto.gov.br/ ccivil_03/_ato2004-2006/2005/decreto/d5440.htm>. Acesso em: 12 dez. 2017.

BRASIL. Lei n 6.938, de 31 de agosto de 1981. Disponível em: <http://www.planalto.gov.br/ ccivil_03/leis/16938.htm>. Acesso em: 12 dez. 2017.

BRASIL. Lei no 9.433, de 8 de janeiro de 1997. Disponível em: <http://www.planalto.gov.br/ccivil_03/ Leis/L9433.htm>. Acesso em: 12 dez 2017.

BRASIL. Lei $\mathbf{n}^{\circ}$ 11.445, de 5 de janeiro de 2007. Disponível em: <http://www.planalto.gov.br/ ccivil_03/_ato2007-2010/2007/lei/l11445.htm>. Acesso em: 12 dez. 2017.

COMISSÃO MUNDIAL SOBRE MEIO AMBIENTE E DESENVOLVIMENTO. Nosso futuro comum. 2 ed. Rio de Janeiro: FGV, 1991.

CONSELHO NACIONAL DE RECURSOS HÍDRICOS (CNRH). Resolução nº 54, de 20 de novembro de 2005. Disponível em: <http://www.cnrh.gov.br/index.php?option=com_docman\&task=doc_ download\&gid=37> . Acesso em: 12 dez. 2017.

CONSELHO NACIONAL DE RECURSOS HÍDRICOS (CNRH). Resolução $\mathbf{n}^{\circ}$ 91, de 5 de novembro de 2008. Disponível em: http://portalpnqa.ana.gov.br/Publicacao/RESOLU\%C3\%87\%C3\%830\%20 CNRH\%20n\%C2\%BA\%2091.pdf>. Acesso em: 12 dez. 2017.

CONSELHO NACIONAL DO MEIO AMBIENTE (CONAMA). Resolução $\mathbf{n}^{\circ}$ 357, de 17 de março de 2005. Disponível em: <http://www.mma.gov.br/ port/conama/legiabre.cfm?codlegi=459>. Acesso em: 12 dez. 2017.

CONSELHO NACIONAL DO MEIO AMBIENTE (CONAMA). Resolução $\mathbf{n}^{\circ} \mathbf{4 3 0}$, de 13 de maio de 2011. Disponível em: <http://www.mma.gov.br/port/ conama/legiabre.cfm?codlegi=646>. Acesso em: 12 dez. 2017.

GONÇALVES, Alcindo. $\mathbf{O}$ conceito de governança. XIV Congresso Nacional CONPEDI. Fortaleza, 2005, p. 1. Disponível em: <http://www.egov.ufsc.br/portal/sites/default/files/conceito_de_ governanca.pdf>. Acesso em: 12 dez. 2017. 
GRANZIERA, Maria Luiza Machado. Direito Ambiental. 4ª ed. São Paulo: Atlas, 2015.

GRANZIERA, Maria Luiza Machado. Direito de Águas - Disciplina Jurídica das Águas Doces. 4. ${ }^{\text {a }}$ ed. São Paulo: Atlas, 2014.

HESPANHOL, Ivanildo. Um novo paradigma para a gestão de recursos hídricos. Revista Estudos Avançados. São Paulo, 2008, v. 22, n. 63, p. 131-158. ISSN 0103-4014. Disponível em: <http:// dx.doi.org/10.1590/S0103-40142008000200009>. Acesso em: 12 dez. 2017.

HOEKSTRA, Arjen Y. Sustainable, efficient, and equitable water use: the three pillars under wise freshwater allocation. WIREs Water, jan./fev. 2014, v. 1, p. 31-40. Doi: 10.1002/wat2.1000. Disponível em: <http://onlinelibrary. wiley.com/doi/10.1002/wat2.1000/full>. Acesso em: 12 dez. 2017.

LBÂNIO, Paulo Augusto Cunha; CHERNICHARO, Carlos Augusto de Lemos; NASCIMENTO, Nilo de Oliveira. A dimensão da qualidade de água: avaliação da relação entre indicadores sociais, de disponibilidade hídrica, de saneamento e de saúde pública. Engenharia Sanitária e Ambiental, Rio de Janeiro, jul/set 2005, v. 10, n. 3. Disponível em: <http://dx.doi.org/10.1590/S141341522005000300006 > . Acesso em: 12 dez. 2017.

MINISTÉRIO DA SAÚDE. Portaria n 2.914, de 12 de dezembro de 2011. Disponível em: <http:// bvsms.saude.gov.br/bvs/saudelegis/gm/2011/prt2914_12_12_2011.html>. Acesso em: 12 dez. 2017.

MOREIRA, Iara Verocai Dias. Vocabulário básico de meio ambiente. Rio de Janeiro: Fundação Estadual de Engenharia do Meio Ambiente (FEEMA), 1990.

ORGANIZAÇÃO PARA A COOPERAÇÃO E DESENVOLVIMENTO ECONÔMICO (OCDE). Princípios da OCDE para a Governança da Água. OCDE, 2015.

ORGANIZAÇÃO DAS NAÇÕES UNIDAS. Agenda 2030. Disponível em: < https://nacoesunidas.org/ pos2015/agenda2030/> . Acesso em: 12 dez. 2017.

SANTOS, Maria Helena de Castro. Governabilidade, governança e democracia: criação de capacidade governativa e relações Executivo-Legislativo no Brasil pós-Constituinte. DADOS - Revista de Ciências Sociais. Rio de Janeiro, 1997, v. 40, n. 3, p. 4. Disponível em: < http://www.scielo.br/scielo. php?script=sci_arttext\&pid=S0011-52581997000300003\&lng=pt\&nrm=iso>. Acesso em: 12 dez. 2017.

UNCED. Agenda 21, United Nations Conference on Environment and Development, Rio de Janeiro, 14 jun. 1992. Disponível em: <https://sustainabledevelopment.un.org/content/documents/ Agenda21.pdf>. Acesso em: 12 dez. 2017.

UNITED NATIONS. A/ARES/64/291. Follow-up to paragraph 143 on human security of the 2005 World Summit Outcome. Disponívelem: <http://www.un.org/en/ga/search/view_doc.asp?symbol=A/ RES/64/291>. Acesso em: 12 dez. 2017.

WORLD BANK. Governance and Development, 1992. Disponível em: < http://documents.worldbank. org/curated/en/604951468739447676/pdf/multi-page.pdf>. Acesso em: 12 dez. 2017. 
ZARED Filho, Kamel; GARCIA Luís Antônio Villaça de; PORTO Mônica Ferreira do Amaral; PORTO, Rubem La Laina. Reúso da água. Escola Politécnica da Universidade de São Paulo Departamento de Engenharia Hidráulica e Sanitária, 2007. Disponível em: <www.pha.poli.usp.br/LeArq.aspx?id_ arq=2151>. Acesso em: 12 dez. 2017.

Recebido em: 06/03/2018

Aprovado em: 06/05/2018 